\title{
Temporal shifts in floristic and avian diversity in Mediterranean pine forest ecosystems under different fire pressure: The island of Zakynthos as a case study
}

\author{
K. Poirazidis, E. Chaideftou, A. Martinis, V. Bontzorlos, P. Galani, D. Kalivas
}

Poirazidis K., Chaideftou E., Martinis A., Bontzorlos V., Galani P., Kalivas D. 2018. Temporal shifts in floristic and avian diversity in Mediterranean pine forest ecosystems under different fire pressure: The island of Zakynthos as a case study. Ann. For. Res. 61(1): 19-36.

Abstract. We evaluated how fire impacts the ecological coherence of Aleppo pine forests and their biodiversity over a 40-year period. The study area forms part of an insular ecosystem of Zakynthos Island (Zante) in western Greece, which forms part of the Ionian Islands. Post-fire effects were studied for both plant and bird diversity at 20 sampling plots, using stratified random sampling, during the summer of 2012. The plots were selected based on the frequency of burning since the 1970s. Sites were categorized as: 1) no burning for $>40$ years, 2) burnt once in the 1970 s, 3) burnt twice, first in the 1970s and again in 2000-2010, 4) burnt three times, first in the $1970 \mathrm{~s}$, and twice more in 2000-2010, and 5) burnt four times, first in the1970s, twice more in 2000-2010, and again in 2011. A total of 79 plant species and 26 bird species were recorded at the studied sites. One-way ANOVA analysis showed that fire intensity has a significant impact on alpha floristic diversity. Average plant species richness at sites that burned in 2011 was significantly higher than in those that burned in the 1970s. Detected differences in bird species richness were not significant; however, more species were documented in the forested habitats (unburnt for $>40$ years, and burnt in the 1970s). The highest Jaccard similarity index was observed between the sites that had not burned for more than 40 years and the sites that burned in the $1970 \mathrm{~s}$. The lowest floristic similarity to non-burnt sites was observed between the recently burnt sites in 2011 and the sites that burned in the 1970 s. The lowest bird similarity was detected between recently burnt sites in 2011 and sites that had not burned for more than 40 years. DCA ordination showed the presence of a clear fire gradient, from intensively burnt open sites to non-burnt forest sites. We suggest that fire is essential to maintain biodiversity in Aleppo pine forests, but only at intermediate frequency. Keywords pinewoods, post-fire impacts, biodiversity, ecological coherence, avifauna, flora, Zakynthos

Authors. Konstantinos Poirazidis, Evgenia Chaideftou (eugeniachd@gmail. com), Aristotelis Martinis - Department of Environment Technology, Techno- 
logical Educational Institute of Ionian Islands, Panagoula, 29100 Zante, Greece; Vasileios Bontzorlos - Center for Research and Technology - Hellas (CERTH), Institute for Bio-Economy and Agri-Technology (iBO), Thessaly, Dimarhou Georgiadi Nikolaou 118, Volos, 38333, Greece; Polixeni Galani, NCC- Nature Conservation Consultants Ltd. Chalandri, Athens, Greece; Dionissios Kalivas, Agricultural University of Athens, Laboratory of Agricultural Chemistry and Soil Science, GIS Research Unit, Iera Odos 75, GR11855 Athens, Greece.

Manuscript received October 16, 2017; revised December 12, 2017; accepted December 14, 2017; online first December 15, 2017.

\section{Introduction}

\section{Forest fires: natural disturbance of forest life cycle}

Forest fires are a form of natural disturbance in forest ecosystems. Fires affect forest composition and structure, as well as vegetation processes through variant succession patterns (Keane et al. 2013). Fires are considered as the most common natural disturbance in forests, particularly pine forests (Agee 1998, Vacchiano et al. 2017), leading to biomass loss that affects thousands of hectares per year (García-Ruiz et al. 2013). Fires also affect the physical, chemical, and biological properties of soils, through the combustion of litter and soil organic matter, which increases the availability of certain nutrients and the volatilization of others. All fires represent a disturbance that reshapes all inter-linked micro- and macro-organisms of all taxa, which form the forest bio-community. The fire impact forces biological response on genetic, species and community level and triggers optimization processes of morphological and biochemical traits and strategies of survival and reproduction (e.g., Kadereit et al. 2014). Fire pressure as a factor of ecological selection culminated in the origin of pyrophilous ('fire-loving') species which are known among plants, fungi, animals including numerous pyrophilous insects (Capinera 2008).

In parts of eastern and southern Europe, fires are considered the most common threats to forests (Krivtsov et al. 2009, Gil-Romera et al. 2010). In the Mediterranean basin, where the 20 incidence of fire is characterized by its high frequency, fire functions both as an eminent threat and as a natural part of forest ecological processes (Rodrigo et al. 2004), forming a major key-process of the forest dynamics (Kazanis \& Arianoutsou 2004, Pausas et al. 2008).

With respect to intensity and extension, repeated fires which occur over the whole extension of a forest, threaten the resilience of the ecosystem. Fire frequency is the number of fire incidents that occur at a given site over a given period of time (Eugenio et al. 2006a), can either threaten or strengthen the resilience of the ecosystem, and is dependent on structural and spatial factors (Koutsias et al. 2012). Within the Mediterranean basin, the incidence of reoccurring fires has increased since the 1960s (Moreno et al. 1998), due to a warming and drying trend, but also due to rural depopulation, land abandonment, and afforestation with flammable species that increase the accumulation of fuel-material (Moreira et al. 2009, Shakesby 2011). According to EC (2013), between 1980 and 2012, the mean fire frequency per square kilometer was 3.2, 3, and 1.2 fires per $\mathrm{km} 2$ of land in Italy, Spain, and Greece, respectively. With global climate change, fire frequencies are expected to increase in the Mediterranean, making forests even more vulnerable (Fyllas et al. 2007, Maia et al. 2014).

\section{A positive role for forest fires?}

Corona et al. (2014) showed that pine forests constitute a major landscape feature of the Mediterranean Basin, accounting for $25 \%$ of the forested Mediterranean surface, with Pi- 
nus halepensis Mill. being the most abundant species. In the western Mediterranean Basin, pine forests account for 2.5 million ha of land (Ganteaume et al. 2009). On average, approximately 600,000 ha of forests burn each year in the Mediterranean. This land transformation also increases the risk of reoccurring forest fires (Krivtsov et al. 2009). More specifically, the recurrent fires that occur in the Mediterranean regions of Spain, southern France, Italy, and Greece are considered as major causes for the decrease of natural forests in this region (López-Bermúdez 2008, García-Ruiz et al. 2013). Because of the high-severity of fires, leading to their being characterized as mega-fires (Miller et al. 2008), a strong negative impact was recorded on forest resilience in the region, in combination with climate change factors (Keane et al. 2013, Fernandes et al. 2017).

Consequently, people commonly perceive fire-shaped forests in the Mediterranean basin as being linked to habitat loss and degradation, rather than as a beneficial fragmentation process (Herrando \& Brotons 2002). When a fire is not a destructive mega-fire, it has a positive role in enriching diversity patterns and richness, a fact that is widely recognized (Taylor 2000). Thus, fire, apart from threatening ecosystem resilience, also represents a key disturbance route to reviving forest landscapes, and is a fundamental element of ecosystem functioning (Sakulich \& Taylor 2007, Gillson 2009). Fires of limited extent create habitat heterogeneity by converting homogeneous woody landscapes into more complex forest-shrub mosaics (Herrando \& Brotons 2002), because they re-introduce early-successional communities within existing mature forests (Brotons et al. 2005, Santos et al. 2009). This process creates forest patches of different age and structure within the same ecosystem; consequently, fires also increase diversity at the landscape scale (gamma-diversity) (Moreira et al. 2001, Blondel et al. 2010). Therefore, it is the extent of fires, their intensity, and differing frequency of occurrence that must be placed under detailed study in each different case in order to assess if fires actually degrade forest ecosystems, or promote species diversity (Tingley et al. 2016), and sustain biodiversity instead of being a major factor for biodiversity loss in the forest ecosystems of southern Europe (Doblas-Miranda et al. 2017).

\section{Post-fire effects on vegetation and avifauna assemblages}

The different degree of post-fire regeneration of forest species, such as the Aleppo pine, in recently burnt forests might create a variety of new landscape features through the process of regeneration (Arianoutsou \& Ne'eman 2000, Rodrigo et al. 2004). For most taxa in a healthy forest ecosystem, diversity and patch connectivity are essential landscape features (Chuvieco et al. 2010). With respect to avifauna, Fuhlendorf et al. (2012) and Standish et al. (2014) showed that birds prefer habitat heterogeneity, and are unlikely to move through degraded, homogeneous rangelands.

However, post-fire effects on vegetation and the avifauna assemblages of Mediterranean forests are complex, and mainly depend on the new conditions created after each fire in each distinct geographical area, as well as the pre-existing floristic and avifauna assemblages and their ecological niches (Viedma 2008, Maia et al. 2014). For instance, avifauna species that are considered to be strictly forest dwellers are strongly affected by forest fires, because they lose their main habitat. In comparison, species with a broader habitat spectrum are able to utilize adjacent areas too, by nesting outside recently burned areas, but also using the newly emerged open areas for foraging (Lowe et al. 2012, Versluijs et al. 2017).

Moreover, because most fires vary in both their intensity and in frequency, it is difficult to generalize their effects (Edenius 2011). Studies on the frequency of fires and post-fire effects mainly use models that predict the fu- 
ture ecological conditions for the landscape and shifts in tree species (Fyllas et al. 2007, Koutsias et al. 2012, Ruiz-Labourdette et al. 2013, Turco et al. 2017). However, knowledge about how an increase in fire frequency affects the diversity of flora remains limited (Kazanis \& Arianoutsou 1996, Eugenio et al. 2006a; 2006b), with only a few studies comparing short-term intervals (1-2 years) in fire incidence with long-term intervals (two to four decades) (Glitzenstein et al. 2012).

\section{Aims of the study}

Here, we evaluated how fires impact on and alter flora and avifauna biodiversity in the Aleppo pine (P. halepensis) forests of Zakynthos Island over a 40-year period (1970-2011). Specifically, we evaluated different temporal fire layers (i.e. regimes), in terms of fire frequency at specific sites and at varied time intervals. We focused on the western part of the island, which is characterized by low mountains covered in Aleppo pine forests that have been subject to repeated incidences of fire. We examined: (i) the total and average species richness and diversity of flora and avifauna at forest sites subject to different frequencies of fire disturbance since the 1970s, (ii) the similarity indices of flora and avifauna for all different layers of fire frequency in the examined forest categories, and (iii) the ordination of vegetation and bird fauna in relation to fire frequency. Our results are expected to provide information on the optimal period between fires that promote species diversity.

\section{Materials and methods}

\section{Study area}

The study area is the island of Zakynthos in western Greece (20.7728, 37.7825). The island forms part of the Ionian Islands, which is an insular system covering a total surface area of $405 \mathrm{~km}^{2}$, holding a total forested area (dense 22 shrubs and pines) of 9,691 ha of which $37 \%$ is comprised mainly by pine forests. The complex mosaic of vegetation types on the island is characterized by high diversity (Kefalas et al. 2016). Habitats include P. halepensis woods, shrubs, meadows, agricultural areas, olive groves, and other habitat types, such as recently burnt open areas and sand dunes, shrub habitats occupy a total of 6,129 ha and there is an additional 3,750 ha of transitional habitats. Zakynthos mainly consist of limestones, especially along its coasts, whereas marly limestones, sandstones, mudstones, marls and evaporites (mainly gypsum) may also be found, while the island's main plain in the eastern part is dominated by alluvial depositions (Evelpidou 2011).

The study area is included in the Natura 2000 network as a Special Protected Area (SPA: GR2210001), and is also recorded as an Important Bird Area (IBA), mainly for bird species associated with scrub and coastal areas. Breeding avifauna in the region include eight out of 21 European species that do not breed in the Mediterranean biome (Portolou et al. 2009). Zakynthos also supports the biggest colony (67 pairs) of breeding Eleonora's falcon (Falco eleonorae) in the Ionian Islands complex (Hellenic Ornithological Society 2007).

Zakynthos has a hot summer Mediterranean-type climate (Csa after Köppen-Geiger climate classification, Peel et al. 2007), with intense annual precipitation ranging from 800 to $900 \mathrm{~mm}$. The wet season starts in September and ends in May (Martinis et al. 2017). The highest altitude is located at the top of Mount Vrachionas, reaching $792 \mathrm{~m}$.

\section{Fire frequency and the history of fire on Zakynthos}

Fires were first documented in the study area during the 1970s; since 2000 small to medium fires have been documented almost every year, with different areas burning. During the summer of 2009 (July-August) more than 80 
distinct fires were recorded on the island, with continuous large wildfires in 2009, 2011, and 2012 leading to the heavy and repeated reburning of the northwestern coast, threatening this part of the island with desertification (Pettas et al. 2015).

The insular ecosystem of Zakynthos contains forest sites that have not been disturbed by fires since 1970; thus, these areas have remained non-burnt for at least 40 years. The different time-layers used in our analysis reflect the fire history of Zakynthos, showing the number of fires and frequency of repetition across various sites (Table 1). The first temporal fire-layer represents forest sites that remained non-burnt since 1970, and is symbolized as 0t. Sites that were burnt once between 1970 and 1980 are symbolized with 1t. Sites that were burnt twice since 1970, with the first incident taking place between 1970 and 1980 and the second between 2000 and 2010 are symbolized with $2 \mathrm{t}$. Sites that were burnt three times since 1970, with the first fire inci- dent taking place between 1970 and 1980, and the two latter incidences taking place between 2000 and 2010, are symbolized with 3t. Sites that were burnt four times, including the incidents of $3 t$ plus the most recent incidence in 2011, are symbolized with $4 \mathrm{t}$.

\section{Field data collection}

Flora and avifauna species were recorded during the spring and summer of 2012 at the 20 study sites, with 4 sites within each one of the five distinct fire-temporal layers using the criterion of the frequency of fires (see Figure 1 for site distribution). Random stratified sampling was applied by selecting four sampling plots randomly within each one of the 20 sites, with a surface of 100 square meters each.

Within each site, plant sampling was realized according to Braun-Blanquet (1964), using quadrat sampling plots of $100 \mathrm{~m}^{2}$. Within each sampling plot, structural vegetation features were recorded, including the percentage

Table 1 Forest type categorization with respect to different ratios of fire repeatability per forest site and per period of occurrence since the 1970s on Zakynthos Island. The period between each fire event and the 2012 field data collection, is also presented

Forest type categorization with respect to fire repeatability and reoccurrence since the 1970s on Zakynthos (in parenthesis the maximum approximate time interval between fire occurrences and the 2012 sampling period)

\begin{tabular}{|c|c|c|c|c|c|}
\hline Time interval & $\begin{array}{l}\text { Forests non- } \\
\text { burnt since } \\
>40 \text { years } \\
\text { 0t }\end{array}$ & $\begin{array}{l}\text { Forest with } 1 \\
\text { fire incidence } \\
\text { 1t }\end{array}$ & $\begin{array}{l}\text { Forest with } 2 \text { fire } \\
\text { incidences } \\
\mathbf{2 t}\end{array}$ & $\begin{array}{l}\text { Forest with } 3 \text { fire } \\
\text { incidences } \\
\text { 3t }\end{array}$ & $\begin{array}{l}\text { Forest with } 4 \\
\text { fire incidences } \\
\mathbf{4 t}\end{array}$ \\
\hline 1970-1980 & & $\begin{array}{l}1^{\text {st }} \text { incidence } \\
\text { (30 years })\end{array}$ & $\begin{array}{l}1^{\text {st }} \text { incidence } \\
\text { (30 years) }\end{array}$ & $\begin{array}{l}1^{\text {st }} \text { incidence } \\
\text { (30 years) }\end{array}$ & $\begin{array}{l}1^{\text {st }} \text { incidence } \\
\text { (30 years) }\end{array}$ \\
\hline \multicolumn{6}{|l|}{ 1981-1990 } \\
\hline \multicolumn{6}{|l|}{$1991-2000$} \\
\hline \multirow[t]{2}{*}{$2001-2010$} & & & $\begin{array}{l}2^{\text {nd }} \text { incidence } \\
\text { (10 years })\end{array}$ & $\begin{array}{l}2^{\text {nd }} \text { and } 3^{\text {rd }} \\
\text { incidence } \\
3 \text { to } 4 \text { years } \\
\text { average between } \\
2 t \text { and } 3 t\end{array}$ & $\begin{array}{l}2^{\text {nd }} \text { and } 3^{\text {rd }} \\
\text { incidence } \\
3 \text { to } 4 \text { years } \\
\text { average } \\
\text { between } 2 t \\
\text { and } 3 \mathrm{t}\end{array}$ \\
\hline & & & & $\begin{array}{l}\left(5 \text { years for } 3^{\text {rd }}\right. \\
\text { incidence) }\end{array}$ & $\begin{array}{l}\left(5 \text { years for } 3^{\text {rd }}\right. \\
\text { incidence })\end{array}$ \\
\hline 2011 & & & & & $\begin{array}{l}4^{\text {th }} \text { incidence } \\
\text { (1 year) }\end{array}$ \\
\hline
\end{tabular}




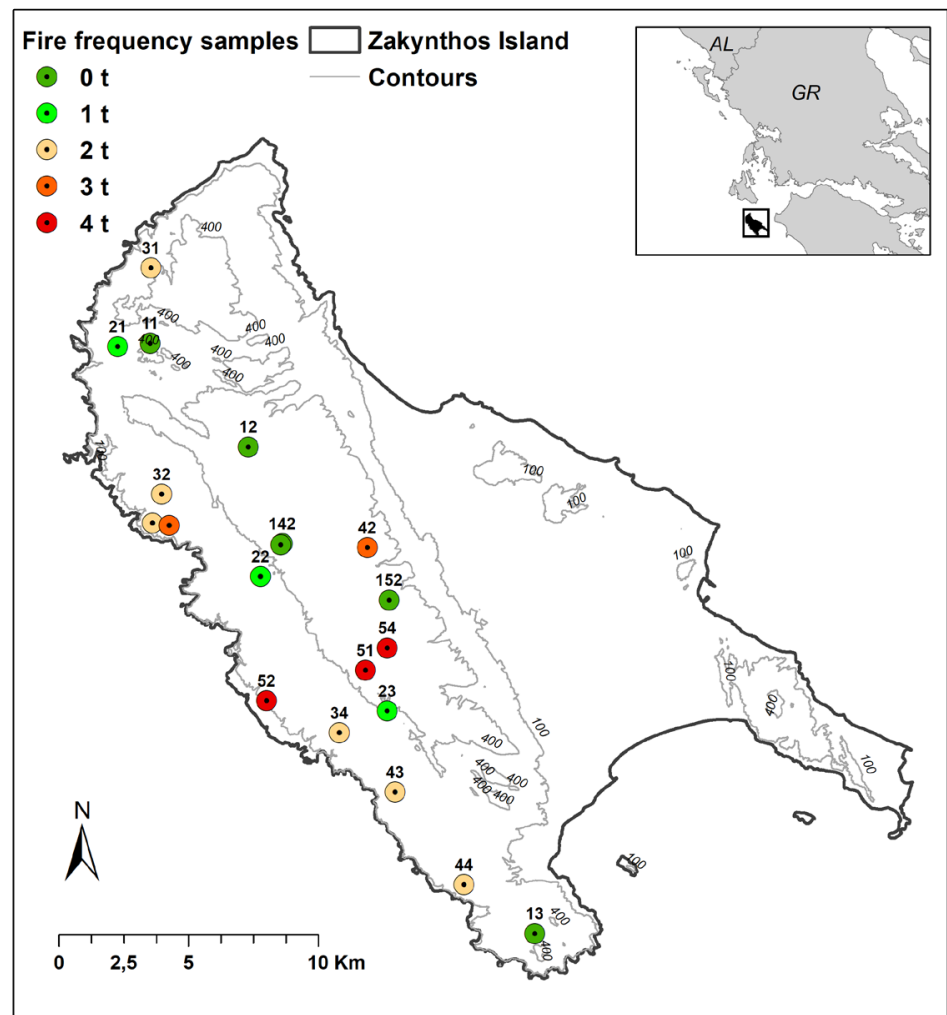

Figure 1 Map showing the locations of the sampling plots regarding the fire frequency on Zakynthos Island, which cover the entire west-central part of the study area in a north-south direction. This region represents the area that has been subject to repeated fire events from the 1970 s to the present day

cover of the sampling area for trees, shrubs, and herb-layers, the height of woody and herbaceous plant species, and of all vegetation layers in meters. Plant taxa were also recorded, in addition to estimating their abundance and/or dominance. The redundancy analysis variables that were incorporated were soil erosion and soil compression estimated according to Nakos (1977), the (\%) percentage of sampling area covered by stones and parent material (Stones/PM), fine-grained soil (\%), bryophytes, and litter, along with litter height $(\mathrm{cm})$ and slope (\%).

Ecological groups were assigned to the plant taxa that were recorded in the study area, based on the criteria of fire-tolerance, following Böh- ling (1995). The taxa were then ranked into four groups accordingly: low tolerant, medium tolerant, resistant and highly resistant (Supporting Information 1).

Avifauna species were recorded with standard point-count methodology, as described by Bibby et al. (2000). For avifauna five point counts were conducted at each site at a distance of 200 $\mathrm{m}$ between points (each audio visual recording lasted $5 \mathrm{~min}$ ).

\section{Data analyses}

For avifauna, the Shannon index was calculated for each sampling area and each fire temporal-layer, providing information on the diversity, evenness of distribution, and abundance (Nur et al. 1999):

$$
\mathrm{H}=\sum_{i=1}^{i=S}\left(p_{i}\right)(\ln p) i=1,2, \ldots, S
$$

where $S$ is the number of species per sampling plot and $p_{i}$ is the percentage of individuals of each species recorded in each sampling plot for species $i$. The index $N_{1}=e H$, which expresses diversity in terms of species numbers, was also used. Comparisons between species abundance and the $N_{1}$ index allow the evenness of species distribution between plots to be estimated. The evenness index $E=H / \ln (S)$ was also used. The total number of plant species that were present per fire frequency temporal layer was also estimated. 
Similarity was estimated using the Jaccard similarity index between fire-disturbed plots $(1 \mathrm{t}-4 \mathrm{t})$ and long-time non-burned sites (0t) through pairwise comparisons. Each of the fire-frequency layer was compared against $0 t$. The recorded differences in species richness and similarity were verified by one-way analysis of variance (1-way ANOVA) with additional post-hoc tests (LSD test).

Vegetation data were analyzed with ordination techniques Detrended Correspondence Analysis (DCA) and Redundancy Analysis (RDA) to correlate plant species samples with the environmental variables at the sampling sites. All ordination analyses were performed using the program CANOCO (ter Braak \& Šmilauer 2002).

\section{Results}

\section{Composition and structure of floristic and avian communities}

Vegetation communities

A total of 79 plant species were recorded in the 20 sampling sites (Supporting Information 2 ). Forests that were not burnt for at least 40 years $(0 t)$ or were burnt only once (1t) had high woody assemblages, with well-developed distinct vegetation layers (herbaceous, low and higher shrubs, and low and higher trees). P. halepensis dominated the higher tree layer, while Pistacia lentiscus L. and Rhamnus alaternus L. dominated the lower tree layer. Dominant species in the shrub layer included Arbutus unedo L., Smilax aspera L., and Rubia peregrina L., with Brachypodium spp. grasses being highly abundant in the forest openings. According to Zakynthos pine forests belong to the habitat type 9540 Mediterranean pine forests with endemic Mesogean pines (subtype 42.848 Greek Aleppo pine forests) (European Union Commission, DG-ENV 2013).

$2 \mathrm{t}$ plots were dominated by $P$. halepensis, followed by P. lentiscus, A. unedo, and Myrtus communis L., with sparse Ceratonia siliqua L.. The species abundance and cover in the shrub layer of $3 t$ plots was different, because tall shrubs were rare, with $P$. lentiscus and $A$. unedo being the dominant species in the higher shrub layer. In the lower shrub layer of $2 \mathrm{t}$ and 3 t plots, Cistus spp. was dominant, while Erica arborea L., Calicotome villosa, Genista acanthoclada, Globularia alypum L., and Thymus capitatus L., were abundant. 3t woody assemblages appeared to become degraded to lower scrubs (phrygana). 4t plots were characterised by simpler assemblages of low woody, mainly aromatic, and legume herbaceous species. Abundant species included: P. lentiscus, Salvia spp., Cistus creticus L., Cistus salvifolius L., $R$. alaternus, Sarcopoterium spinosum L., $G$. acanthoclada, T. capitatus, and the rare Fumana thymifolia L. Dorycnium spp. and Convolvulus spp. were present at lower abundances. The cushion-forming thermo-Mediterranean sclerophyllous formations, often thorny and summer deciduous belong to the habitat type 5420 Sarcopoterium spinosum phryganas (European Union Commission, DG-ENV 2013)

\section{Avifauna communities}

A total of 26 species were recorded in the study area; one nocturnal raptor and two diurnal raptors, two columbiformes and 21 passerines. Most bird species (15) were recorded in sampling plots within 1t plots. Sixteen species were recorded in $0 \mathrm{t}$, and thirteen species in $2 \mathrm{t}$ and $3 \mathrm{t}$ plots, respectively. $4 \mathrm{t}$ sites contained the lowest numbers of individuals (57) and species (11) (Table $2 \&$ Supporting Information 3).

The most abundant species was the Sardinian warbler (Sylvia melanocephala Gmelin) in $1 \mathrm{t}$ sites and the house sparrow (Passer domesticus L.) in $2 t$ plots. The Sardinian warbler was encountered in all sampling plots. In all five forest categories, both the house sparrow and European serin (Serinus serinus L.) were recorded, but with varying abundance.

In shrub and maquis areas ( $2 \mathrm{t}$ and $3 \mathrm{t}$ ), the crested lark (Galerida cristata L.) and wood- 
chat shrike (Lanius senator L.) were exclusively recorded. In comparison, the cirl bunting (Emberiza cirlus L.) was the only open area species recorded in 1t plots. Forest avian species that were exclusively recorded within 0t plots included the Eastern olivaceous warbler (Iduna pallida Ehrenberg), olive-tree warbler (Hippolais olivetorum Strickland), spotted flycatcher (Muscicapa striata Pallas), coal tit (Periparus ater L.), and Eurasian scops owl (Otus scops L.).

The Olive-tree warbler is an Annex I species in the Birds Directive 2009/147, and was the only endangered species that was recorded in the study area. Other avian species that do not hold stable populations based on their European status were mainly encountered in $3 \mathrm{t}$ plots.

Avian diversity indices were higher in 1 t plots (Table 3 ), whereas the $4 \mathrm{t}$ plots had the lowest diversity and evenness values.

\section{Analysis of variance for floristic and avian diversity}

One-way analysis of variance showed that the frequency of fires significantly affected plant taxa alpha-diversity (plant taxa richness) $(F=5.875, d f=4, p=0.005)$. With respect to the fire frequency temporal layers, the highest species richness for plants (54 species) was detected in $4 \mathrm{t}$ plots, and was significantly higher compared to: (i) $0 \mathrm{t}$ plots ( $p=0.001, \mathrm{LSD})$, (ii) $1 \mathrm{t}$ plots ( $p=0.002$, LSD), and (iii) $3 \mathrm{t}$ plots $(p=0.033$, LSD) (Figure 2a).

In comparison, the observed differences in avian diversity were not statistically significant $(F=$ $0.433, d f=4, p=0.783$ ) (Figure 2b).

\section{Jaccard similarity indices}

A statistically significant effect was detected on similarity between $0 \mathrm{t}$ and $1 \mathrm{t}-4 \mathrm{t}$ plots for both flora $(F=16.676, d f=3, p<0.001)$ and avifauna $(F=6.395, d f=3, p=0.001)$. The highest similarity was detected between $0 \mathrm{t}$ and 1 t plots for both flora ( $p<0.001$, LSD; Figure 3) and avifauna ( $p=0.002$, LSD; Figure 4 ) diversity datasets. The lowest similarity for plant diversity was detected between the sites that were repeatedly burnt $(2 \mathrm{t}-4 \mathrm{t})$ and $0 \mathrm{t}$ plots (Figure 3).
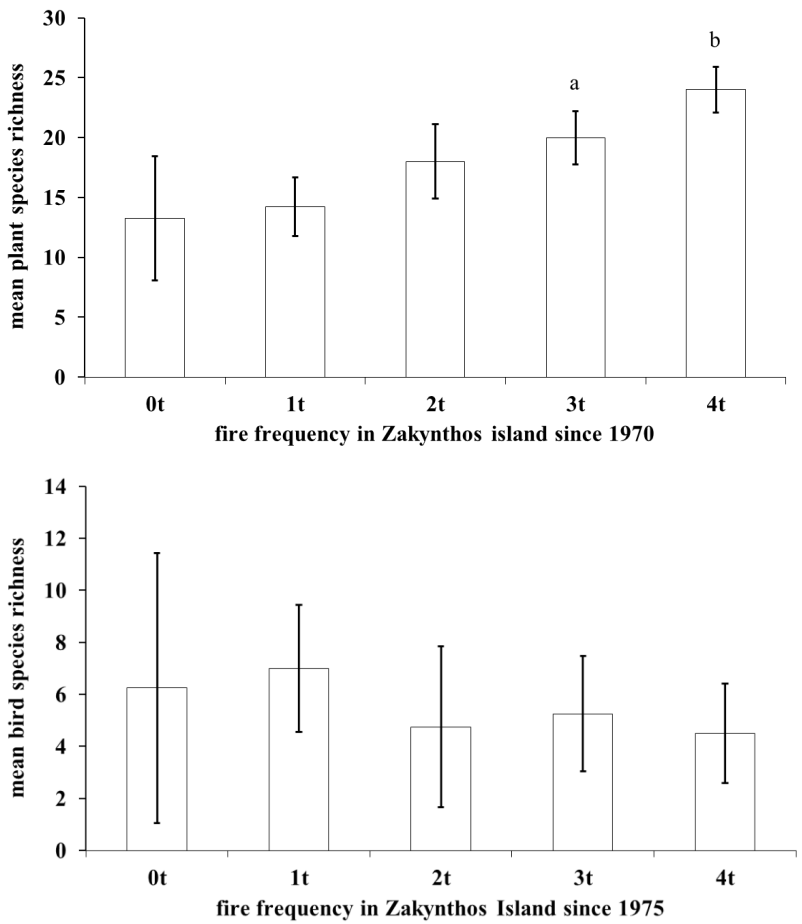

Figure 2 Plant (a - up) and bird (b - down) species richness on Zakynthos Island in areas exposed to different frequencies of fire throughout the study period. Areas that were burnt three and four times exhibited significantly higher richness than areas that were not burnt or were burnt just once or twice (a: significantly higher, $p<$ 0.05 ) than $0 \mathrm{t}$ and $1 \mathrm{t}$, b: significantly higher than $0 \mathrm{t}, 1 \mathrm{t}$, and $2 \mathrm{t}(p<0.01))$. Differences in bird diversity were not statistically significant. 


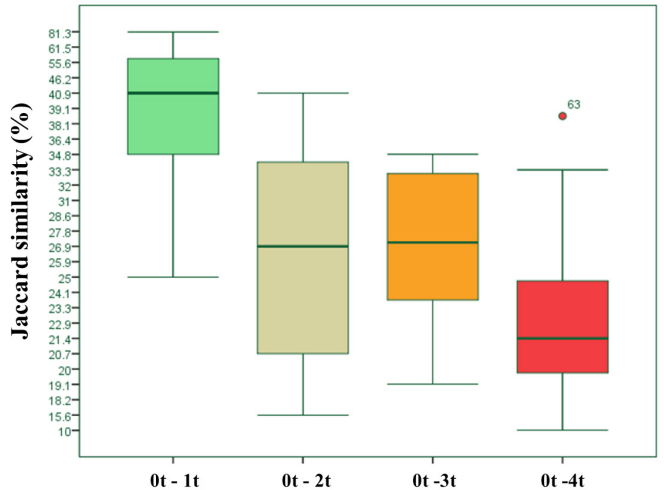

Figure 3 Jaccard similarity for flora between nonburnt and burnt sites with different frequencies of fire. Pairwise comparisons: $0 \mathrm{t}$ - 1t: comparisons between non-burnt forests since 1970 and forests that were burnt once since 1970, 0t - 2t: comparisons between non-burnt forests since 1970 and forests that were burnt twice, $0 \mathrm{t}$ - 3t: comparisons between non-burnt forests since 1970 and forests that were burnt three times since 1970, and $0 \mathrm{t}-4 \mathrm{t}$ : comparisons between non-burnt forests since 1970 and forests that were burnt four times, with the most recent incident occurring in 2011.

\section{Ordination analyses of vegetation and avifau- na communities}

\section{Detrended Correspondence Analysis (DCA) for vegetation and avifauna}

Ordination analyses of plant taxa generated a clear fire-frequency gradient, from higher to lower fire frequency intensity, creating a reducing gradient along Axis 1. Eigenvalues of 0.30 and 0.14 corresponded to axes 1 and 2, respectively, representing $22.1 \%$ and $32.4 \%$ of variation for plant taxa data (Figure 5).

A similar ordination was created for avifauna in relation to fire frequency (Figure 6), which clearly distinguished densely forested ( $0 t$ and 1t) and less-forested (3t and 4t) (phrygana)

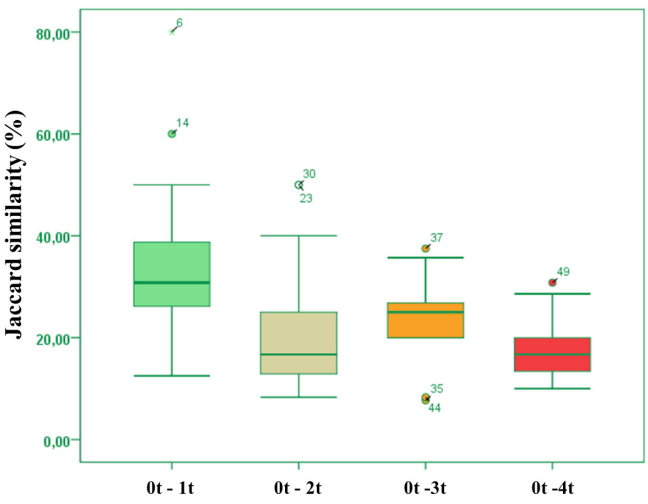

Figure 4 Jaccard similarity for avifauna between non-burnt and burnt sites with different frequencies of fire. Pairwise comparisons were: $0 \mathrm{t}-1 \mathrm{t}$ : comparisons between nonburnt forests since 1970 and forests that were burnt once since 1970, 0t - 2t: comparisons between non-burnt forests since 1970 and forests that were burnt twice, $0 \mathrm{t}$ - 3t: comparisons between non-burnt forests since 1970 and forests that were burnt three times since 1970, and $0 \mathrm{t}-4 \mathrm{t}$ : comparisons between non-burnt forests since 1970 and forests that were burnt four times, with the most recent incident occurring in 2011.

sites. Eigenvalues were 0.53 and 0.35 for axes 1 and 2 , respectively, representing $17.2 \%$ and $28.6 \%$ of the cumulative variation in bird taxa data.

Redundancy Analysis (RDA) of vegetation community structure

RDA grouped the sampling plots under high fire intensity $(2 t, 3 t$ and $4 t)$ in the left part of the diagram, and were positively correlated with soil erosion, soil compaction, the percentage cover of stones and parent material, and slope (Figure 7). In comparison, 0t plots were grouped in the right part of the RDA diagram, and were positively correlated with bryophytes, percentage litter cover, litter height, 

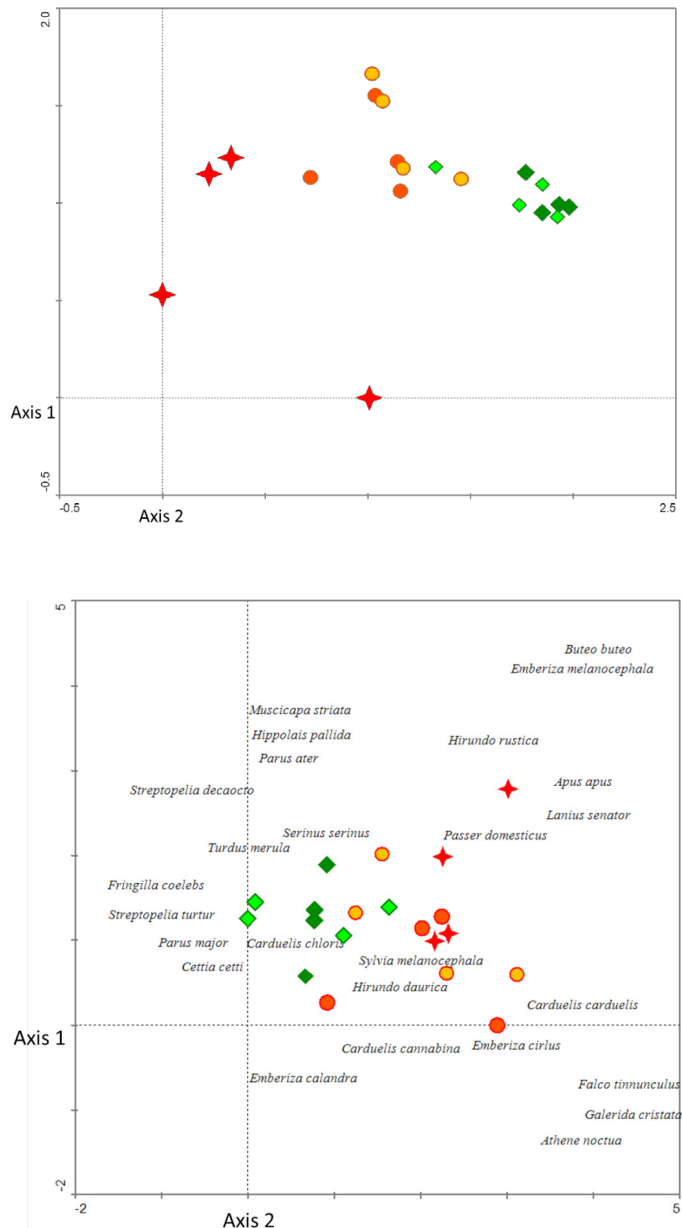

\section{Figure 5}

Jaccard similarity for flora between non-burnt and burnt sites with different frequencies of fire. Pairwise comparisons: 0t - 1t: comparisons between non-burnt forests since 1970 and forests that were burnt once since 1970, $0 \mathrm{t}-2 \mathrm{t}$ : comparisons between non-burnt forests since 1970 and forests that were burnt twice, $0 \mathrm{t}$ - $3 \mathrm{t}$ : comparisons between non-burnt forests since 1970 and forests that were burnt three times since 1970, and 0t - 4t: comparisons between non-burnt forests since 1970 and forests that were burnt four times, with the most recent incident occurring in 2011.

\section{Figure 6}

DCA ordination diagram of avifauna species at sites with different frequencies of fire on Zakynthos Island. Dark-green rhombus - non-burnt forest since 1970; light-green rhombus - forests that were burnt once since 1970, with fires occurring between 1970 and 1980; orange circle - forests that were burnt twice since 1970, with the first incidence occurring in 1970-1980 and the second occurrence in 20002010; red rhombus - forests that were burnt three times since 1970, with the first occurrence in 19701980 and the two last occurrences between 2000 and 2010; and forests that were burnt four times, with first occurrence in 1970-1980, the next two occurrences in 2000-2010, and the final occurrence in 2011. Italics indicate recorded avian species. Lengths of gradient: 3.115 (Axis 1) and 2.785 (Axis 2).

and the percentage of fine-grained soil cover. Eigenvalues were 0.174 and 0.077 on axes 1 and 2 , respectively, representing $17.4 \%$ and $25.1 \%$ of the cumulative variation of plant taxa data, and $37.4 \%$ and $54.0 \%$ of the cumulative percentage variance of species-environment relationships.

The RDA diagram showed that most xerophytic plant taxa typical of lower scrub Mediterranean habitats (phrygana) were mainly aggregated in the left part of the redundancy diagram. Likewise, the cluster of plant species that exhibited intermediate to high resistance to fire, according to Böhling (1995), were clus- tered in the left part of the diagram (Figure 6).

\section{Discussion}

\section{Optimum temporal intervals of fire reoccur- rence}

Our data showed that forest sites that have been disturbed once or twice by fire with an average time interval of 30 years supported higher plant species richness than non-burnt sites, even though this difference was not statistically significant (Table 1, Figure 2a). 


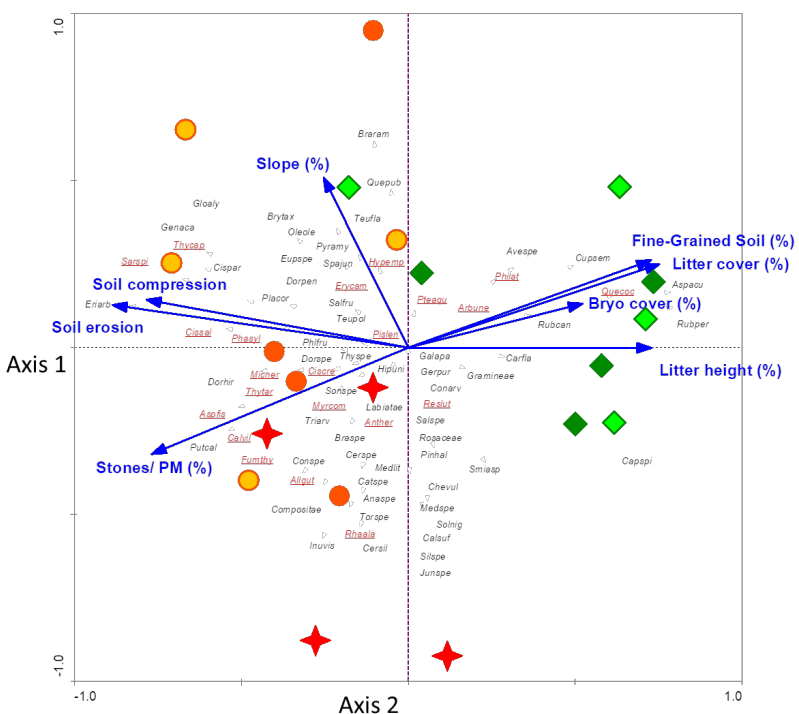

\section{Figure 7}

Redundancy analysis (RDA) triple diagram demonstrating vegetation species, sampling plots, and environmental variables. Sampling plots are indicated with different geometric shapes (circles, stars, and rhombus) and colors indicating the frequency of fires: Dark-green rhombus - non-burnt forest since 1970; light-green rhombus - forests that were burnt once since 1970, with fires occurring between 1970 and 1980; orange circle - forests that were burnt twice since 1970, with the first incidence occurring in 1970-1980 and the second occurrence in 2000-2010; red rhombus - forests that were burnt three times since 1970, with the first occurrence in 1970-1980 and the two last

occurrences between 2000 and 2010; and forests that were burnt four times, with first occurrence in 19701980, the next two occurrences in 2000-2010, and the final occurrence in 2011. Italics demonstrate plant species, with red underlined italics denoting fire tolerant plant species. Plant species names are explained in Supplementary Table 2. Blue vectors indicate environmental variables. Eigenvalue 0.174 (Axis 1 ) and 0.077 (Axis 2). Percentage of explained species-environmental variables variance: 0.937 (Axis 1) and 0.886 (Axis 2); Cumulative percentage variance of species data: 17.4 (Axis 1) and 25.1 (Axis 2); Cumulative percentage variance of species-environment relation: 37.4 (Axis 1) and 54.0 (Axis 2); Sum of all eigenvalues: 1.000 and Sum of all canonical eigenvalues: 0.466 .

Of note, when the time interval between fires decreased to an average of five to ten years, plant species richness significantly increased (Table 1, Figure 2a), whereas avian diversity decreased, but not significantly (Figure $2 b$ ). In addition, the habitats that newly emerged after repeated burning, with an average regime of five years, caused radical changes to both their vegetation composition (Figure 3) and avian diversity (Figure 4). This change occurred because open area habitats were created that attracted different bird species. An exception was the presence of Sardinian warbler in all plots, showing the capacity of this species to adapt to multiple habitats of different quality. Our study supports a similar study conducted in the pine forests of southern USA, which showed that high plant species richness could be gained if fires occur at frequencies of six to seven year intervals (Beckage \& Stout 2000). The authors suggested a six to seven year minimum threshold in fire-frequency intervals, proposing that shorter periods would cause a decline in species richness, leading to habitat loss and desertification processes.

Under the spectrum of fire-treatment experiments, and when considering the impacts of fire intervals to forest ecosystems, Glitzenstein et al. (2012) suggested that species richness in the south-eastern coastal plains of the USA was significantly higher in pine forests that had been burned versus not burned. The authors also placed a minimum threshold of six to seven years for fire reoccurrence to positively revive the pine-forest ecosystem. Brockway \& Lewis (1997) also obtained similar findings for pine savannas. Moreover Glitzenstein et al. (2012) concluded that shorter year intervals 
(e.g. 4-year) are more likely to lead to noteworthy shifts in species composition with herb dominance in understory vegetation layers.

In comparison, a study of plant species responses to varied fire-frequency in a mosaic of Mediterranean mixed cork-oak ( $Q$. suber, $Q$. pubescens and $Q$. ilex) woodlands with maquis shrubs dominated by Cistus species and Erica arborea and shrub-lands in southern France (Schaffhauser et al. 2012) showed that longer periods between fires were the optimum. The authors argued that the numbers of plant resprouters were three to four times lower in sites that were frequently burned over a 50year period. The authors stated that average intervals of 10-15 years between fires were not adequate for certain species to recover and build reserves. Therefore, the authors proposed a period of 10-15 years between fires, or shorter periods, as negative resilience threshold for similar cork-oak dominated communities in Mediterranean ecosystems.

\section{Vegetation and avifauna community structure under different fire regimes}

Ecological datasets often demonstrate a high percentage of unexplained random and spatial variation in the structure of the vegetation community (Gauch 1982). Especially for floristic data, low percentages of explained variation are often anticipated when a large number of rare species of low abundance appear in the datasets (ter Braak \& Smilauer 2002). DCA ordination of the vegetation structure on Zakynthos Island also produced low percentages of explained variation, showing the discrepancies in species composition. Yet, the ordination depicted clear trends in the clustering of species and groups. Significant differences in floristic richness were detected in our study plots, mainly between the most frequently burnt sites (3t, $4 \mathrm{t}$ ), and the less frequently burnt (1t) and the unburnt sites (0t), supporting previous studies in Mediterranean forests of P. halepensis (Kazanis \& Arianoutsou 2002, 2004; Capitanio \&
Carcaillet 2008). The results of these studies indicate a maximum of alpha diversity in the initial post-fire phase and a second maximum of alpha diversity in the transitional post-fire phase towards the dominance of $P$. halepensis. A second maximum was not obtained for plant species richness (alpha diversity) in our study. Instead, we recorded a decline in plant species richness as the time interval until the next fire increased, supporting a previous small scale study (meters squared) in South African fynbos (Schwilk et al. 1997).

DCA analysis verified a clear gradient from non-burnt (0t) to the most frequently burnt (4t) forest plots, while RDA analysis showed that most species (many of which were tolerant or resistant to fire) were aggregated at higher fire frequency intensity (Figure 7). Most importantly, the $3 \mathrm{t}$ and $4 \mathrm{t}$ plots of the current study had a species-rich low-shrub understory that contained many woody species typical of low, simplified xerophytic and fire-tolerant assemblages in the Mediterranean (phrygana). These plots were subject to fire around five to six years before sampling in 2012 (3t) (Table $1)$. Vegetation similarity to the non-burnt plots was highly different between forest patches of Habitat type 9540 burnt once (1t) and phrygana plots of Habitat type 5420 that were burnt four times (4t).

Tingley et al (2016) also concluded that community structure is promoted by variation in the intensity of frequent fires. However, Schaffhauser et al. (2012) stated that selection and replacement are dynamic processes that influence plant communities as a result of fire recurrence at short intervals (Lloret et al. 2003). These events cause the depletion of both resprouters and seeders, which require a longer period of time to recruit (Curt et al. 2009). Thus, highly frequent fires of very short intervals in Mediterranean-type ecosystems might cause a shift in the pre-dominant vegetation because more sensitive species go extinct (Eugenio-Gosalbo et al. 2006a). Thus, to explain the frequency of fires in each distinct 
geographical area, it is important to develop objective descriptive parameters that include all environmental parameters (Fernandes et al. 2017).

Maia et al. (2014) investigated post-fire regeneration of Pinus pinaster plantations in Portugal subject to five to seven year intervals of fire management, and showed that the most important variables that affect postfire processes are region and slope. These parameters also explain shrub species richness, pinpointing the importance of region-specific post-fire management practices and post-fire management. Similarly, local fire history, regeneration, and topography probably contribute to the variability in the impact of fires on ecosystems and landscapes in distinct regions (Viedma 2008).

\section{Similarity indices between plots of different fire frequencies and implications}

Vegetation similarity to the non-burnt plots was highly different between forest patches burnt once (1t) and plots that were burnt four times (4t). We attributed the observed differences to high variation in both alpha and gamma diversity between sites, which occur because of different regeneration periods and fire frequency (Reilly et al. 2006, Capitanio \& Carcaillet 2008). In comparison, plots that were subject to two to three fires with average intervals of five to ten years (between the last fire incidences) had highly similar plant species compositions (Figure 3 ) of plant communities or habitats, supporting previous studies (Capitanio \& Carcaillet 2008). A study of Aleppo pine forest regeneration after low intensity fires (of one year intervals) showed that pre-fire species were still present in post-fire vegetation, with both woody and herbaceous vegetation being present (Buhk et al. 2006), as in the current study.

Our results showed that local factors are a major driving force of bird colonization in open habitats following fire, such as the characteristics of the region, supporting previous studies
(Brotons et al. 2005). For instance, in a given area, bird diversity in the open sites during early period after fire is mainly determined by the degree of habitat suitability before fire. Werema (2015) showed that bird species diversity before forest-fires was significantly higher than that after fire. In comparison, Edenius (2011) showed that bird populations were not negatively affected three years post-fire; however, the author acknowledged the significance of the sampling scale, fire size and intensity, and the adaptability of bird species.

Edenius (2011) also stressed that, if the avifauna species present in forest or open habitats are generalists, they are more likely to adjust quickly to the effects of fire disturbance on forest flora. In contrast, Albanesi et al. (2014) found a strong correlation between specialist forest bird species and low fire disturbance, but also between forest and generalist species with moderate fire disturbance. Our study showed that the number of bird species was particularly low in the most frequently burnt forest patches. Species diversity in the burnt sites might also be directly dependent on the adjacent areas because species disperse there from burnt areas; inversely, the proximity to areas of high diversity might affect the diversity of bird species in the burnt areas following fire events. Moreover, there was no statistically significant difference in the similarity of species presence and abundance of individuals in areas with different frequencies of fire. However, we obtained a stronger correlation between the $2 \mathrm{t}$ and $3 \mathrm{t}$ plots, because the burnt sites were covered by low shrub complex assemblages in both plots. Of particular interest is the fact that there was significant correlation between the $0 \mathrm{t}$ and $1 \mathrm{t}$ forest patches, implying that the burnt pine forests' avian assemblages are enhanced over that of non-burnt forest. This difference is partly explained by the fact that many of the species considered to be depleted at European level are not purely forest species. These bird species were mainly found in the $2 \mathrm{t}$ plots. 


\section{Present status and future implications}

The results of the current study indicate that the ecosystems of Zakynthos Island exhibit sound post-fire recovery. Puerta-Piñero et al. (2012) demonstrated that long-standing forests show higher post-fire recovery than younger. Furthermore, post-fire recovery is faster when more time has passed since abandonment from a management practice; thus, land history routes are useful to estimate the impacts of disturbance on ecosystems. For instance, a study on vegetation responses to fire activity during the Holocene in Iberia showed that, historically, the Mediterranean vegetation of $\mathrm{P}$. halepensis has the fastest post-fire vegetation dynamics over time (Gil-Romera et al. 2010). Thus, it would be interesting to investigate whether future fires of pronounced frequency in the study area (and elsewhere) actually favor shifts in species traits and responses (Retana et al. 2002, Doblas-Miranda et al. 2017).

\section{Conclusions}

The results of the current study showed that $P$. halepensis forests exhibit remarkable postfire recovery. We showed that floristic diversity and similarity increase under varied fire frequencies, supporting the results of Tingley et al. (2016) who demonstrated that biodiversity is promoted by diverse fire frequency. We suggest that fire might be essential to maintain biodiversity in Aleppo pine forests, but at an intermediate frequency, supporting the "Intermediate Disturbance Hypothesis (IDH)" (Wilkinson 1999). Future management measures should be directed towards conserving landscape heterogeneity, given that mosaics that are shaped by varied fire intensity result in high species diversity, supporting the "Heterogeneous Disturbance Hypothesis (HDH)" (Warren et al. 2007). Landscape structure has a strong potential at mitigating the impacts of fire on the coherence of Mediterranean ecosys- tems (Tingley et al. 2016).

\section{Acknowledgements}

The present study was conducted in the frame of the INTERREG IV - NAT PRO project that was implemented on Zakynthos Island of Greece by the Technological Educational Institute of the Ionian Islands. We acknowledge our partners for their work field in the frame of the project: Roxanne-Suzette Lorilla, Georgios Kefalas, and Nikos Promponas. Special thanks to Dr Gail Schofield for the review and linguistic editing of the text. We also acknowledge the help of two anonymous reviewers.

\section{References}

Agee J.K., 1998. Fire and pine ecosystems. In: Richardson D.M. (ed.), Ecology and biogeography. Cambridge University Press, Cambridge, pp. 193-218.

Albanesi S., Dardanelli S., Bellis L.M., 2014. Effects of fire disturbance on bird communities and species of mountain Serrano forest in central Argentina. Journal of Forest Research 19(1): 105-114. DOI: $10.1007 / \mathrm{s} 10310-$ 012-0388-4

Arianoutsou M., Ne'eman G., 2000. Post-fire regeneration of natural Pinus halepensis forest in the east Mediterranean Basin. ?n G. Ne'eman and L. Trabaud (eds.). Ecology, Biogeography and Management of Pinus halepensis and P. brutia Forest Ecosystems in the Mediterranean Basin. Backhuys, Leiden, The Netherlands, pp. 269-290.

Beckage B., Stout I.J., 2000. Effects of repeated burning in Florida pine savannas: a test of the intermediate disturbance hypothesis. Journal of Vegetation Science 11: 113-122. DOI: $10.2307 / 3236782$

Bibby C.J., Burgess N.D., Hill D.A., Mustoe S., 2000. Bird Census Techniques, Academic Press Inc., 302 p.

Blondel J., Aronson J., Bodiou J.Y., Boeuf G., 2010. The Mediterranean Region. Biological Diversity in Space and Time. Oxford University Press, New York, 392 p.

Böhling N., 1995. Zeigerwerte der Phanerogamen-Flora von Naxos (Griechenland). Ein Beitrag zur ökologischen Kennzeichnung der mediterranen Pflanzenwelt [Indicator values of the phanerogams' flora of Naxos (Greece). A contribution to the ecological classification of the Mediterranean flora]. Stuttgarter Beitr. Naturk., Ser. A (Biologie), 533 p.

Braun-Blanquet J., 1964. Pflanzensoziologie - Grundzüge der Vegetationskunde [Plant sociology; the study of 
plant communities]. 3rd edn, Springer-Verlag, 365 p. DOI: 10.1007/978-3-7091-8110-2

Brockway D.G., Lewis C.E., 1997. Long-term effects of dormant-season prescribed fire on plant community diversity, structure and productivity in a longleaf pine wiregrass ecosystem. Forest Ecology and Management 96: 167-183. DOI: 10.1016/S0378-1127(96)03939-4

Brotons L., Pons P., Herrando S., 2005. Colonization of dynamic Mediterranean landscapes: where do birds come from after fire? Journal of Biogeography 32: 789798. DOI: 10.1111/j.1365-2699.2004.01195.x

Buhk C., Götzenberger L., Wesche K., Sánchez Gómez P. and Hensen I., 2006. Post-fire regeneration in a Mediterranean pine forest with historically low fire frequency. Acta Oecologica 30: 288-298. DOI: 10.1016/j. actao.2006.05.010

Capinera J.L., (ed.), 2008. Encyclopedia of Entomology, 2nd edn., Springer, Berlin Heidelberg, 4346 p. DOI: 10.1007/978-1-4020-6359-6

Capitanio R., Carcaillet C., 2008. Post-fire Mediterranean vegetation dynamics and diversity. A discussion of succession models. Forest Ecology and Management 255: 431-439. DOI: 10.1016/j.foreco.2007.09.010

Chuvieco E., Aguado I., Yebra M., Nieto H., Salas J., Martín M.P., Vilar L., Martínez J., Martín S., Ibarra P., de la Riva J., Baeza J., Rodríguez F., Molina J.R., Herrera M.A., Zamora R., 2010. Development of a framework for fire risk assessment using remote sensing and geographic information system technologies. Ecological Modelling 221: 46-58. DOI: 10.1016/j.ecolmodel.2008.11.017

Corona P., Ferrari B., Cartisano R., Barbati A., 2014. Calibration assessment of forest flammability potential in Italy. iForest 7: 300-305.

Curt T., Adra W., Borgniet L., 2009. Fire-driven oak regeneration in French Mediterranean ecosystems. Forest Ecology and Management. 258: 2127-2135. DOI: 10.1016/j.foreco.2009.08.010

Doblas-Miranda E., Alonso R., Arnana X., Bermejo V., Brotons L., de las Heras J., Estiarte M., Hódar J.A., Llorens P., Lloret F., López-Serrano F.R., Martínez-Vilalta J., Moya D., Pe-uelas J., Pino J., Rodrigo A., Roura-Pascual N., Valladares F., Vilà M., Zamora R., Retana J., 2017. A review of the combination among global change factors in forests, shrublands and pastures of the Mediterranean Region: Beyond drought effects. Global and Planetary Change 148: 42 54. DOI: 10.1016/j.gloplacha.2016.11.012

Edenius L., 2011. Short-term effects of wildfire on bird assemblages in old pine- and spruce-dominated forests in northern Sweden. Ornis Fennica 88: 71-79.

Eugenio Gosalbo M., Verkaik I., Lloret F. and Espelta J.M., 2006a. Recruitment and growth decline in Pinus halepensis populations after recurrent wildfires in Catalonia (NE Iberian Peninsula). Forest Ecology and Management 231: 47-54. DOI: 10.1016/j.foreco.2006.05.007

Eugenio Gosalbo M., Lloret F., Alca-iz J.M., 2006b. Regional patterns of fire recurrence effects on calcareous soils of Mediterranean Pinus halepensis communities. Forest Ecology and Management 221: 313-318. DOI: 10.1016/j.foreco.2005.10.011

European Commission (EC), 2013. Forest Fires in Europe, Middle East and North Africa 2012. Publications Office of the European Union, Luxembourg, 107 p.

European Union Commission, DG-ENV, 2013. Interpretation Manual of the European Union Habitats - EUR28. 1-144.

Evelpidou N., 2011. Modelling of erosional processes in the Ionian islands. Geomatics, Natural Hazards and Risks 3(4): 293-310. DOI: 10.1080/19475705.2011.604798

Fernandes P.M., Guiomar N., Mateus P., Oliveira T., 2017. On the reactive nature of forest fire-related legislation in Portugal: A comment on Mourão and Martinho (2016). Land Use Policy 60: 12-15. DOI: 10.1016/j. landusepol.2016.10.008

Fuhlendorf S.D., Engle D.M., Elmore R.D., Limb R.F., Bidwell T.G., 2012. Conservation of pattern and process: developing an alternative paradigm of rangeland management. Rangeland Ecology and Management 65: 579-589. DOI: 10.2111/REM-D-11-00109.1

Fyllas N.M., Phillips O.L., Kunin W.E., Matsinos Y.G., Troumbis A.I., 2007. Development and parameterization of a general forest gap dynamics simulator for the North-eastern Mediterranean Basin (GREek FOrest Species). Ecological Modelling 204: 439-456. DOI: 10.1016/j.ecolmodel.2007.02.006

Ganteaume A., Jappiot M., Lampin-Maillet C., Curt T., Borgniet L., 2009. Fuel characterization and effects of wildfire recurrence on vegetation structure on limestone soils in southeastern France. Forest Ecology and Management 258: 15-23. DOI: 10.1016/j.foreco.2009.07.021

García-Ruiz J-M., Nadal-Romero E., Lana-Renault N., Beguería S., 2013. Erosion in Mediterranean landscapes: Changes and future challenges. Geomorphology 198: 20-36. DOI: 10.1016/j.geomorph.2013.05.023

Gauch H.G.Jr., 1982. Multivariate analysis in community ecology. Cambridge University Press, Cambridge, UK.

Gil-Romera G., Carrion J.S., Pausas J.G., Sevilla-Callejo M., Lamb H.F., Fernandez S., Burjachs F., 2010. Holocene fire activity and vegetation response in South-Eastern Iberia. Quaternary Science Reviews 29: 1082-1092. DOI: 10.1016/j.quascirev.2010.01.006

Gillson L. 2009. Landscapes in time and space. Landscape Ecology 24: 149-155. DOI: 10.1007/s10980-008-93157

Glitzenstein J.S., Streng D.R., Masters R.E., Robertson K.M., Hermann S.M., 2012. Fire-frequency effects on vegetation in north Florida pinelands: Another look at the long-term Stoddard Fire Research Plots at Tall Timbers Research Station. Forest Ecology and Management 264: 197-209. DOI: 10.1016/j.foreco.2011.10.014

Hellenic Ornithological Society, 2007. Database for Falco eleonorae 2004-2007. LIFE - Nature "Conservation actions for Falco eleonorae in Greece" (LIFE03 NAT/ GR/000091). 
Herrando S., Brotons L., 2002. Forest bird diversity in Mediterranean areas affected by wildfires: A multiscale approach. Ecography 25(2): 161-172. DOI: 10.1034/j.1600-0587.2002.250204.x

Kadereit J.W., Körner C., Kost K, Sonnewald U. (eds.), 2014: Strasburger Lehrbuch der Pflanzenwissenschaften [Strasburger's textbook of Botany], 37th ed., Springer, Berlin Heidelberg, 919 p. DOI: 10.1007/9783-642-54435-4

Kazanis D., Arianoutsou M., 1996. Vegetation composition in a post-fire successional gradient of Pinus halepensis forest in Attica, Greece. International Journal of Wildland Fires 6(2): 83-91. DOI: 10.1071/WF9960083

Kazanis D., Arianoutsou M., 2002. Long term post-fire vegetation dynamics in Pinus halepensis forests of Central Greece: plant community patterns. In: Viegas D.X. (ed). Proceedings of the 4th international Conference of Forest Fire Research, Millpress, The Netherlands, electronic edition.

Kazanis D., Arianoutsou M., 2004. Factors determining low Mediterranean ecosystem resilience to fire: the case of Pinus halepensis forests. In: Arianoutsou M. \& Papanastasis V. (eds.), Proceedings of 10th MEDECOS Conference, April 25-May 1 2004, Rhodes, Greece, Millpress Rotterdam, ISBN 9059660161.

Keane R.E., Cary G.J., Flannigan M.D., Parsons R.A., Davies I.D., King K.J., Li C., Bradstock R.A., Gill M., 2013. Exploring the role of fire, succession, climate, and weather on landscape dynamics using comparative modeling. Ecological Modelling 266: 172-186. DOI: 10.1016/j.ecolmodel.2013.06.020

Kefalas G., Poirazidis K., Kalogirou S., Martinis A., 2016. Dynamic variation of land use/cover changes and landscape in Ionian Islands complex. 8th Greek Ecology Conference, Thessaloniki, 20-23 October 2016.

Koutsias N., Arianoutsou M., Kallimanis A.S., Mallinis G., Halley J.M., Dimopoulos P., 2012. Where did the fires burn in Peloponnisos, Greece the summer of 2007 ? Evidence for a synergy of fuel and weather. Agricultural and Forest Meteorology 156: 41-53. DOI: 10.1016/j. agrformet.2011.12.006

Krivtsov V., Vigy O., Legg C., Curt T., Rigolot E., Lecomte I., Jappiot M., Lampin-Maillet C., Fernandes P., Pezzatti G.B., 2009. Fuel modelling in terrestrial ecosystems: An overview in the context of the development of an object-orientated database for wild fire analysis. Ecological Modelling 220: 2915-2926. DOI: 10.1016/j. ecolmodel.2009.08.019

Lachance D., Lavoie C., 2004. Vegetation of Sphagnum bogs in highly disturbed landscapes: relative influence of abiotic and anthropogenic factors. Applied Vegetation Science 7: 183-192. DOI: 10.1658/1402-2001(2004)007[0183:VOSBIH]2.0. $\mathrm{CO} ; 2$

Lloret F., Pausas J.G., Vilà M., 2003. Responses of Mediterranean plant species to different fire frequencies in Garraf Natural Park (Catalonia, Spain): field observations and modelling. Plant Ecology 223-235. DOI:
10.1023/A:1023911031155

López-Bermúdez F., 2008. Desertificación: Preguntas y respuestas a un desafío económico, social y ambiental [Desertification: Questions and answers about an economic, social and environmental challenge]. Fundación Biodiversidad, Madrid, $129 \mathrm{p}$.

Lowe J., Pothier D., Rompré G., Savard J.P.L., 2012. Long-term changes in bird community in the unmanaged post-fire eastern Québec boreal forest. Journal of Ornithology 153: 1113-1125. DOI: 10.1007/s10336012-0841-3

Maia P., Keizer J., Vasques A., Abrantes N., Roxo L., Fernandes P., Ferreira A., Moreira F., 2014. Post-fire plant diversity and abundance in pine and eucalypt stands in Portugal: Effects of biogeography, topography, forest type and post-fire management. Forest Ecology and Management 334: 154-162. DOI: 10.1016/j.foreco.2014.08.030

Martinis A., Chaideftou E., Minotou Ch., Poirazidis ?. 2017. Spatial analysis, Hot Spots and orchids diversity in Zante Island. Proceedings of the Annual Meeting of Prosilva Europe, 8-11 October 2017, Edessa, Greece.

Miller J.D., Safford H.D., Crimmins M., Thode A.E., 2008. Quantitative evidence for increasing forest fire severity in the Sierra Nevada and Southern Cascade Mountains, California and Nevada, USA. Ecosystems 12: 16-32. DOI: 10.1007/s10021-008-9201-9

Moreira F., Vaz P., Catry F., Silva J.S., 2009. Regional variations in wildfire susceptibility of land-cover types in Portugal: implications for landscape management to minimize fire hazard. International Journal of Wildland Fire 18(5): 563-574. DOI: 10.1071/WF07098

Moreira F., Ferreira P.G., Rego F.C., Bunting S., 2001. Landscape changes and breeding bird assemblages in northwestern Portugal: the role of fire. Landscape Ecology 16: 175-187. DOI: 10.1023/A:1011169614489

Moreno J.M., Vázquez A., Veléz R., 1998. Recent history of forest fires in Spain. In: Moreno, J.M. (ed.), Large Forest Fires. Backhuys Publishers, Leiden, the Netherlands, pp. 159-185.

Nakos G., 1977. Soil map of Greece. General Directorate of Forests and Natural Environment, Institute of Forest Research, Athens.

Nur N., Jones S.L., Geupel, G.R., 1999. A statistical guide to data analysis of avian monitoring programs. U.S. Department of the Interior, Fish and Wildlife Service, BTP-R6001-1999, Washington D.C, 61 p.

Pausas J.C., Llovet J., Rodrigo A., Vallejo R., 2008. Are wildfires a disaster in the Mediterranean basin? A review. International Journal of Wildland Fire 17(6): 713723. DOI: 10.1071/WF07151

Peel M.C., Finlayson B.L., McMahon T.A., 2007. Updated world map of the Köppen-Geiger climate classification. Hydrolology and Earth Systems Science 11: 16331644. DOI: $10.5194 /$ hess-11-1633-2007

Pettas H., Poirazidis K., Daneli N., Martinis A., Lattas P., 2015. Evaluation of post-fire natural restoration indices with the use of remote sensing data. Proceedings of the 
17th Greek Forestry Conference: "The contribution of modern forestry and protected areas in sustainable development". Hellenic Forestry Society, 4-7 October 2015, Kefallinia, pp. 499-508.

Portolou D., Bourdakis S., Vlachos C., Kastritis T., Dimalexis T., 2009. Important Bird Areas of Greece: Priority Areas for Biodiversity Conservation. Hellenic Ornithological Society, Athens [In Greek].

Puerta-Pi-ero C., Espelta J.M., Sánchez-Humanes B., Rodrigo A., Coll L., Brotons L., 2012. History matters: Previous land use changes determine post-fire vegetation recovery in forested Mediterranean landscapes. Forest Ecology and Management 279: 121-127. DOI: 10.1016/j.foreco.2012.05.020

Reilly M.J., Wimberly M.C., Newell C.L., 2006. Wildfire effects on plant species richness at multiple spatial scales in forest communities of the southern Appalachians. Journal of Ecology 94: 118-130. DOI: 10.1111/j.1365-2745.2005.01055.x

Retana J., Espelta J.M., Habrouk A., Ordó-ez J.L., de Solà-Morales F., 2002. Regeneration patterns of three Mediterranean pines and forest changes after a large wildfire in northeastern Spain. Ecoscience 9: 89-97. DOI: $10.1080 / 11956860.2002 .11682694$

Rodrigo A., Retana J., Picó F.X., 2004. Direct regeneration is not the only response of Mediterranean forests to large fires. Ecology 85(3): 716-729. DOI: 10.1890/020492

Ruiz-Labourdette D., Schmitz M.F., Pineda F.D., 2013. Changes in tree species composition in Mediterranean mountains under climate change: Indicators for conservation planning. Ecological Indicators 24: 310-323. DOI: 10.1016/j.ecolind.2012.06.021

Sakulich J., Taylor A.H., 2007. Fire regimes and forest structure in a sky island mixed conifer forest, Guadalupe Mountains National Park, Texas, USA. Forest Ecology and Management 241: 62-73. DOI: 10.1016/j. foreco.2006.12.029

Santos X., Bros V., Mino A., 2009. Recolonization of a burned Mediterranean area by terrestrial gastropods. Biodiversity Conservation 18: 3153-3165. DOI: 10.1007/s10531-009-9634-2

Schaffhauser A., Curt T., Véla E., Tatoni T., 2012. Fire recurrence effects on the abundance of plants grouped by traits in Quercus suber L. woodlands and maquis. Forest Ecology and Management 282: 157-166. DOI: 10.1016/j.foreco.2012.06.047

Schwilk D.W., Keeley J.E., Bond W.J., 1997. The intermediate disturbance hypothesis does not explain fire and diversity pattern in fynbos. Plant Ecology 132: 77-84. DOI: 10.1023/A:1009755320731

Shakesby R.A. 2011. Post-wildfire soil erosion in the Mediterranean: Review and future research directions. Earth-Science Reviews 105: 71-100. DOI: 10.1016/j. earscirev.2011.01.001

Standish J.R., Hobbs R.J., Mayfield M.M., Bestelmeyer B.T., Suding K.N., Battaglia L.L., Eviner V., Hawkes C.V., Temperton V.M., Cramer V.A., Harris J.A.,
Funk J.L., Thomas P.A., 2014. Resilience in ecology: Abstraction, distraction, or where the action is? Biological Conservation 177: 43-51. DOI: 10.1016/j.biocon.2014.06.008

Taylor A.H., 2000. Fire regimes and forest changes in mid and upper montane forests of the southern Cascades, Lassen Volcanic National Park, California, USA. Journal of Biogeography 27: 87-104. DOI: 10.1046/j.13652699.2000.00353.x

ter Braak C.J.F., Šmilauer P., 2002. CANOCO reference manual and CanoDraw for Windows user's guide: software for canonical community ordination (version 4.5). Microcomputer power, Ithaca, New York, USA, $500 \mathrm{p}$.

Tingley M.W., Ruiz-Gutierrez V., Wilkerson R.L., Howell C.A., Siegel R.B., 2016. Pyrodiversity promotes avian diversity over the decade following forest fire. Proceedings of the Royal Society B 283: 20161703. DOI: 10.1098/rspb.2016.1703

Turco M., Levin N., Tessler N., Saaroni H., 2017. Recent changes and relations among drought, vegetation and wildfires in the Eastern Mediterranean: The case of Israel. Global and Planetary Change 151: 28-35. DOI: 10.1016/j.gloplacha.2016.09.002

Vacchiano G., Garbarino M., Lingua M., Motta R., 2017. Forest dynamics and disturbance regimes in the Italian Apennines. Forest Ecology and Management 388: 5766. DOI: 10.1016/j.foreco.2016.10.033

Versluijs M., Eggers S., Hjältén J., Löfroth T., Roberge J.M., 2017. Ecological restoration in boreal forest modifies the structure of bird assemblages. Forest Ecology and Management 401: 75-88. DOI: 10.1016/j.foreco.2017.06.055

Viedma O., 2008. The influence of topography and fire in controlling landscape composition and structure in Sierra de Gredos (Central Spain). Landscape Ecology 23(6): 657-672. DOI: 10.1007/s10980-008-9228-5

Warren S.D., Holbrook S.W., Dale D.A., Whelan N.L., Elyn M., Grimm W., Jentsch A., 2007. Biodiversity and the Heterogeneous Disturbance Hypothesis. Restoration Ecology 15: 606-612. DOI: 10.1111/j.1526100X.2007.00272.X

Werema C., 2015. Understorey bird abundance and diversity before and after a forest fire in Mangala Forest Reserve on the eastern slopes of the Uluguru Mountains, Tanzania. Scopus Journal of East African Ornithology 34: 40-46.

Wilkinson D.M., 1999. The Disturbing History of Intermediate Disturbance. Oikos 84:145-147. DOI: $10.2307 / 3546874$

\section{Supporting Information}

The online version of the article includes Supporting Information: 
Supporting Information 1. Assignment of plant species to ecological groups with the criterion of fire tolerance

Supporting Information 2. Presence of plant species per fire frequency layer

Supporting Information 3. Presence of bird species per fire frequency layer 